\title{
MANAJEMEN PERUBAHAN DAN TEKNOLOGI USAHATANI DI KABUPATEN LOMBOK TIMUR
}

\author{
LALU MUH. KABUL
}

\author{
Sekolah Tinggi Manajemen Informatika dan Komputer Mataram
}

\begin{abstract}
ABSTRAK
Penelitian ini membahas manajemen perubahan, yakni perubahan dalam manajemen usaha tani semula dari penggunaan tenaga kerja manusia dalam pengolahan tanah menjadi teknologi (traktor).Metode penelitian yang digunakan adalah kuantitatif.Hasil penelitian menunjukkan bahwa terjadi perubahan keragaan usaha tani pada tiga komponen, yaitu produktivitas, efisiensi dan biaya usaha tani. Disisi lain, teknologi (traktor) bersifat endogenous, sehingga berpengaruh secara langsung terhadap produksi pertanian (padi). Perkembangan petani tidaklah statis, melainkan dinamis.Untuk itu, strategi pengembangan teknologi digali dari ide (gagasan) petani itu sendiri dan selanjutnya dijadikan topik penelitian terapan oleh berbagai lembaga penelitian dan hasil penelitian tersebut selanjutnya oleh pihak swasta dapat dikembangkan menjadi teknologi terapan untuk petani.
\end{abstract}

e-mail: Kabullpp@yahoo.com

Kata kunci: Manajemen perubahan, teknologi, usaha tani

\section{ABSTRACT}

This study discusses management of change, namely changes in farm management that were originally from the use of human labor into the use of technology (tractors) in tillage. The research method used is quantitative. On the one hand the results of the study indicate that there is a change in farm business performance in three components, namely productivity, efficiency and farming costs. On the other hand, technology (tractors) is endogenous, so that it directly affects agricultural production (rice). The development of farmers is not static, but dynamic. For this reason, the technology development strategy is developed from the ideas sof the farmers themselves and is subsequently used as the topic of applied research by various research institutions and the results of such research will then be developed by the private sector into applied technology for farmers.

Keywords: Change management, technology, farm business

\section{PENDAHULUAN}

\section{Latar Belakang}

Manajemen berasal dari kata Latin manus artinya mengontrol dengan tangan (Hughes, 2011).Manajemen sebagai ilmu atau manajemen ilmiah dipelopori oleh Federick W.Taylor yang dikenal sebagai Bapak Manajemen fokus pada penanganan hubungan antara orang atau tenaga kerja dan tugasnya dalam proses produksi untuk mencapai efisiensi. Menurut Federick W.Taylor proses produksi akan menjadi lebih efisien jika waktu dan usaha yang dikeluarkan oleh orang atau tenaga kerja untuk menghasilkan produk (barang atau jasa) dapat dikurangi. Dalam perkembangannya manajemen ilmiah berkembang menjadi dua pendekatan, yaitu manajemen administrasi dipelopori oleh Henri Fayol dan manajemen birokrasi dipelopori oleh Max Weber (Stacey, 2014).

Disisi lain dalam ilmu manajemen dikenal pendekatan hubungan manusia yang dipelopori oleh Elton Mayo dengan menekankan pada pentingnya interaksi manusia di tempat kerja serta pemenuhan kebutuhan tenaga kerja yang berdampak pada produktivitas kerja.Pendekatan ini kemudian melahirkan teori kebutuhan Abraham Moslow, teori motivasi Herzberg, teori Douglas McGregor mengenai teori X dan teori Y (Gunter, 2014).Selain pendekatan tersebut, dalam manajemen juga digunakan pendekatan sistem yang dipelopori oleh Ludwig von Bertalanffy, Peter Senge.Pendekatan sistem ini memandang semua komponen dalam organisasi antar satu komponen dengan komponen lainnya saling berinteraksi dan menciptakan sistem yang lebih luas (Bratton, 2015). 
Pendekatan baru dalam manajemen terus berkembang dengan digunakannya pendekatan kontingensi yang dipelopori oleh Fied Fiedler. Pendekatan ini memandang tidak ada satu cara terbaik dalam mengelola bisnis karena situasi bisnis ditentukan oleh faktor internal dan eksternal. Pendekatan ini kemudian melahirkan teori situasi dari Hersey dan Blanchard, teori keputusan Vroom dan Yetton (Bratton, 2015).Dalam pada itu, perkembangan terbaru dari teori manajemen, yakni digunakannya pendekatan teori chaos dalam manajemen yang dikenal dengan manajemen chaos.Dalam pada itu, istilah "chaos" berasal dari kata khaos dalam bahasa Yunani yang berarti kekacauan.Dalam teori chaos yang dipelopori oleh Henri Poincare dan Edward Lorenz dikenal istilah efek kupu-kupu (butterfly effect) dimana kepak saya kupu-kupu di Brazil dapat memicu topan tornado di Texas.

Penggunaan teori chaos ini dalam manajemen antara lain dipelopori oleh Tom Peters melalui karyanya "Thriving on Chaos: Handbook for a Management Revolution" (Burns, 2016). Dalam pada itu, efek kupukupu dari teori chaos kemudian dalam manajemen dimaknai sebagai sebuah perubahan kecil dalam situasi tertentu yang memicu dampak besar dan menyeluruh dalam organisasi atau sistem.Berkaitan dengan adanya perubahan tersebut, maka yang menjadi fokus manajemen chaos adalah manajemen perubahan.Dalam manajemen perubahan terdapat tigalangkah perubahan yang dikenal sebagai tiga langkah perubahan Kurt Lewin, yaitu pencairan (unfreeze), perubahan (change), dan pembekuan kembali (refreeze) (Cumming et al, 2016). Pencairan (unfreeze) berarti meninggalkan, menanggalkan, membuangperilaku dan kebiasaan lama, perubahan (change) yakni bergerak ke arah perilaku dan kebiasaan baru, pembekuan kembali (refreeze) adalah mengadopsi, menerapkan, menggunakan perilaku dan kebiasaan baru. Menurut Baker Scott (2017) bahwa perubahan Kurt Lewin tersebut sebenarnya identik dengan unlearning dan relearning dimana unlearning berarti meninggalkan, menanggalkan, membuang perilaku dan kebiasaan lama yang diperoleh dari pelajaran (learning) sebelumnya. Sedangkanrelearning adalah mengadopsi, menggunakan, menerapkan perilaku dan kebiasaan baru.

Kabupaten Lombok Timur dihadapkan pada kekurangan tenaga kerja di sektor pertanian seiring dengan derasnya migrasi Tenaga Kerja Indonesia (TKI) asal Lombok Timur dengan tujuan Malaysia baik melalui jalur legal maupun ilegal. Menurut Haris (2002) dalam konteks ekonomi, faktor pendorong migrasi tersebut adalah upah dimana upah di sektor pertanian di daerah asal, yakni Lombok Timur berkisar antara Rp.2.500Rp.4.000 sementara upah di Malaysia sebagai daerah tujuan dapat mencapai Rp.8.000-Rp.15.000. Dalam pada itu, kelompok migran tersebut didominasi oleh kelompok tenaga kerja usia produktif (15-39 tahun) yakni sebesar 83,20 persen. Disisi lain, kekurangan tenaga kerja di sektor pertanian umumnya terjadi pada pekerjaan pengolahan tanah. Dalam konteks manajemen usaha tani, pengolahan tanah merupakan pekerjaan yang relatif membutuhkan tenaga kerja yang lebih besar dibandingkan pekerjaan lainnya (Djamhari, 2009).

Akibat terjadinya kekurangan tenaga kerja dalam kegiatan usaha tani di Lombok Timur, utamanya dalam pekerjaan pengolahan tanah, maka dalam manajemen usaha tani terjadi perubahan dari unlearning yakni meninggalkan, menanggalkan, membuang perilaku dan kebiasaan sebelumnya yang menggunakan tenaga kerja manusia menjadi relearning yakni mengadopsi, menggunakan, menerapkan teknologi mekanisasi pertanian, yakni traktor sebagai perilaku dan kebiasaan baru dalam usaha tani.Dengan berkurangnya tenaga kerja tersebut menurut Haris (2002) maka biaya produksi usaha tani meningkat melebihi biaya sebelumnya karena ongkos yang dikeluarkan juga meningkat.Selain itu, Haris (2002) menyatakan bahwa kekurangan tenaga kerja juga dapat menimbulkan berkurangnya tingkat produktivitas di sektor pertanian.

Apa yang dikemukakan Haris (2002) berlaku jika kegiatan usaha tani hanya mengandalkan tenaga kerja manusia maupun ternak, tanpa adanya inovasi teknologi. Kalaupun ada teknologi, tetapi teknologi tersebut dianggap sebagai faktor eksogen atau faktor diluar proses produksi usaha tani,sehingga tidak memiliki pengaruh secara langsung terhadap produksi.Para ekonom neoklasik menganggap teknologi sebagai faktor eksogen (Romer,1994).Lebih jauh dinyatakan oleh Romer (1994) bahwa teknologi bukanlah faktor eksogen dalam proses produksi, melainkan merupakan faktor endogen yang melekat dalam proses produksi itu sendiri, sehingga dengan sendirinya teknologi berpengaruh secara langsung terhadap produksi. Berkat teorinya ini, Romer meraih Nobel Ekonomi pada tahun 2018. Berkaitan dengan hal tersebut, maka penelitian ini dilakukan untuk memverifikasi apa yang dikemukakan Haris (2002) dengan fokus permasalahan adalah apakah terdapat perbedaan antara keragaan usaha tani setelah penggunaan teknologi (traktor) dibandingkan dengan penggunakan tenaga kerja manusia (konvensional).

Penelitian ini juga dilakukan untuk memverifikasi teknologi sebagai faktor endogen yang dikemukakan Romer (1994) dengan fokus permasalahan adalah apakah teknologi sebagai faktor endogen dalam manajemen usaha tani berpengaruh secara langsung terhadap produksi pertanian.Selanjutnya adalah bagaimana manajemen strategispengembangan teknologi yang bersifat endogen tersebut (teknologi 
endogenous).Penelitian ini dilaksanakan di Kabupaten Lombok Timur pada tahun 2018 dengan ruang lingkup pada usaha tani tanaman pangan, utamanya padi.

\section{Rumusan Masalah}

Rumusan permasalahan dalam penelitian ini adalah sebagai berikut: (1) apakah terdapat perbedaan keragaan usaha tani setelah penggunaan teknologi (traktor) dibandingkan secara konvensional (tenaga kerja manusia), (2) apakah teknologi (traktor) sebagai faktor endogen dalam manajemen usaha tani berpengaruh secara langsung terhadap produksi pertanian, (3)bagaimana manajemen strategispengembangan teknologi yang bersifat endogen (teknologi endogenous).

\section{Tujuan Penelitian}

Penelitian ini dilaksanakan dengan tujuan sebagai berikut: (1) menganalisisperbedaankeragaan usaha tani setelah penggunaan teknologi (traktor) dibandingkan dengan secara konvensional (tenaga kerja manusia), (2) menganalisis pengaruh langsung teknologi (traktor) sebagai faktor endogen dalam manajemen usaha tani terhadap produksi pertanian, (3) mendeskripsikan manajemen strategis pengembangan teknologi yang bersifat endogen (teknologi endogenous).

\section{METODE PENELITIAN}

\section{Metode pendekatan}

Dalam penelitian ini digunakan pendekatan kuantitatif, yakni kuantitatif komparatif dan kuantitatif asosiatif kausal (Kathori CR dan Gaurav G, 2010).Pendekatan kuantitatif komparatif digunakan untuk menganalisis perbedaan keragaan usaha tani setelah penggunaan teknologi (traktor) dibandingan dengan penggunaan tenaga kerja manusia (konvensional).Pendekatan kuantitatif asosiatif kausal digunakan untuk menganalisis pengaruh langsung teknologi sebagai faktor endogen dalam manajemen usaha tani terhadap produksi pertanian (padi).Dalam pada itu, untuk mendeskripsikan manajemen strategis pengembangan teknologi endogenous digunakan pendekatan deskriptif (Kathori CR dan Gaurav G, 2010).

Penelitianini dilaksanakan di Kabupaten Lombok Timur pada tahun 2018 dengan sampel sebanyak 52 rumah tangga tani.Pengumpulan data dilakukan melalui observasi partisipatif dan wawancara terstuktur dengan berpedoman pada kuisioner.

\section{Variabel dan Analisis}

Variabel penelitian ini meliputi keragaan usaha tani, produksi pertanian dan teknologi, strategi pengembangan teknologi. Variabel keragaan usaha tani meliputi tiga komponen, yaitu produktivitas, curahan kerja, biaya pengolahan tanah. Untuk menganalisis perbedaan ketiga komponen tersebut setelah penggunaan teknologi (traktor) dibandingkan dengan penggunaan tenaga kerja manusia (konvensional) digunakan Uji Z.Dalam pada itu, Uji Z digunakan karena sampel (n) dalam penelitian ini sebanyak 58 rumah tangga tani $(n>30)$, jika sampel (n) sebanyak 30 atau kurang $(n \leq 30)$ maka digunakanUji t (Anderson, 2010).

Variabel produksi pertanian dan teknologi dianalisis dengan menggunakan model Romer (1994) dirumuskan dari fungsi Cobb-Douglas $Y=A K^{\alpha} L^{1-\alpha}$ dimana $\mathrm{Y}$ adalah produksi pertanian (padi) kemudian A adalah teknologi (traktor), $\mathrm{K}$ adalah biaya usaha tani dan $\mathrm{L}$ adalah tenaga kerja manusia. Dalam model Romer (1994) nilai $\alpha$ sama dengan $1(\alpha=1)$, sehingga fungsi Cobb-Douglas tersebut dalam model Romer menjadi $\mathrm{Y}=\mathrm{AK}$ dan jika $\mathrm{A}$ dan $\mathrm{K}$ disimbolkan dengan $\mathrm{X}$, maka model Romer menjadi $\mathrm{Y}=\mathrm{f}(\mathrm{X} 1, \mathrm{X} 2)$, sehingga persamaan regressi dalam model Romer, yaitu $\mathrm{Y}=\mathrm{a}+\mathrm{b} 1 \mathrm{X} 1+\mathrm{b} 2 \mathrm{X} 2$ dimana $\mathrm{Y}$ adalah produksi pertanian (padi), X1 adalah biaya usaha tani dan X2 adalah teknologi (traktor). Dalam pada itu, strategi pengembangan teknologi dianalisis dengan menggunakan Field Force Analysis (Swanson DJ et al, 2014).

\section{HASIL DAN PEMBAHASAN}

\section{Keragaan Usaha Tani}

Keragaan usaha tani meliputi tiga komponen, yaitu produktivitas, curahan kerja, dan biaya pengolahan tanah ditampilkan pada tabel 1. Produktivitas pertanian (padi) yang diperoleh dari penggunaan teknologi (traktor) sebesar 6,83 ton/Ha atau lebih tinggi secara sangat signifikan dibandingkan produktivitas padi yang 
diperoleh secara konvensional (tenaga kerja manusia) sebesar 5,98 ton/Ha dan hal ini ditunjukkan oleh hasil Uji Z sebesar 2,673 dengan sign.0,002 $(0,002<0,01)$.

Disisi lain, penggunaan teknologi (traktor) lebih efisien dibandingkan secara konvensional (tenaga kerja manusia) dimana curahan kerja berupa Hari Orang Kerja (HOK) dengan penggunaan teknologi (traktor), yakni sebesar 4,93 HOK lebih rendah secara sangat signifikan dibandingkan curahan kerja secara konvensional sebesar 13,45 HOK dan hal ini ditunjukkan oleh hasil Uji Z sebesar 2,549 dengan sign.0,003 $(0,003<0,01)$. Biaya pengolahan tanah dengan penggunaan teknologi (traktor) adalah sebesar Rp.1.104.000 per hektar lebih rendah secara signifikan dibandingkan secara konvensional (tenaga kerja manusia) sebesar Rp.2.125.000 per hektar dan ini ditunjukkan oleh hasil Uji Z sebesar 2,357 dengan sign.0,032 $(0,032<0,05)$.

Tabel 1. Perbandingan Keragaan Usaha Tani antara Traktor dan Konvensional

\begin{tabular}{|l|c|c|c|c|}
\hline Keragaan Usaha Tani & Teknologi & Konvensional & $\mathrm{Z}$ & Sign. \\
\hline Produktivitas (ton/Ha)** & 6,83 & 5,98 & 2,673 & 0,002 \\
\hline Curahan Kerja (HOK)** & 4,93 & 13,45 & 2,549 & 0,003 \\
\hline $\begin{array}{l}\text { Biaya pengolahan tanah* } \\
\text { (Rp000/Ha) }\end{array}$ & 1.104 & 2.125 & 2,357 & 0,032 \\
\hline
\end{tabular}

Sumber: Data Primer Diolah

Keterangan: **signifikan pada taraf nyata 1 persen (sangat signifikan)

*signifikan pada taraf nyata 5 persen (signifikan)

Menurut Haris (2002)kekurangan tenaga kerja di sektor pertanian di Lombok Timur terjadi karena adanya migrasi tenaga kerja asal Lombok Timur ke Malaysia dan kekurangan tenaga kerja tersebut menimbulkan berkurangnya produktivitas pertanian dan meningkatnya biaya usaha tani. Hasil penelitian ini berbeda dengan Haris (2002) dimana dengan berkurangnya tenaga kerja justru terjadi manajemen perubahan usaha tani semula dari konvensional (tenaga kerja manusia) menjadi penggunaan teknologi (traktor) dimana produktivitas pertanian (padi) yang diperoleh dari penggunaan teknologi (traktor) tersebut lebih tinggi secara sangat signifikan dibandingkan secara konvesional (tenaga kerja manusia) dan biaya usaha tani (pengolahan tanah) dengan penggunaan teknologi (traktor) lebih rendah secara signifikan dibandingkan secara konvensional (tenaga kerja manusia).

\section{Produksi Pertanian dan Teknologi}

Berdasarkan hasil penelitian ini diperoleh model Romer (1994) dalam bentuk persamaan regressi sebagai berikut: $\mathrm{Y}=-1.045+2,127 \mathrm{X} 1+3,549 \mathrm{X} 2$. Kedua variabel bebas yaitu biaya usaha tani $(\mathrm{X} 1)$ dan teknologi/traktor $(\mathrm{X} 2)$ berpengaruh secara simultan dan sangat signifikan terhadap produksi pertanian $(\mathrm{Y})$ sebagai variabel terikat dan hal ini ditunjukkan oleh Uji F sebesar 24,753 dengan signifikansi sebesar 0,001 $(0,001<0,01)$.Selain itu, pengaruh kedua variabel bebas tersebut baik biaya usaha tani (X1) maupun teknologi/traktor X2 masing-masing secara parsial terhadap variabel terikat ditunjukkan oleh hasil Uji t. Dalam pada itu, biaya usaha tani (X1) berpengaruh signifikan terhadap produksi pertanian/padi (Y) dan ditunjukkan oleh Uji t sebesar 2,947 dengan signifikansi sebesar 0,027 $(0,027<0,05)$ danteknologi/traktor (X2) berpengaruh sangat signifikan terhadap produksi pertanian/padi (Y) dan ditunjukkan oleh Uji t sebesar 3.989 dengan signifikansi sebesar 0,002 $(0,002<0,01)$. Hasil model Romer (1994) dalam persamaan regressi ditampilkan pada tabel 2.Lebih jauh dari persaman regressi tersebut diperoleh produk marginal (PM) untuk kapital/biaya usaha tani ( $\partial \mathrm{Y} / \partial \mathrm{X} 1)$ sebesar 2,127 dan produk marginal untuk teknologi/traktor ( $\partial \mathrm{Y} / \partial \mathrm{X} 2)$ sebesar 3,549. Hal ini menunjukkan bahwa PM untuk biaya usaha tani maupun teknologi (traktor) lebih dari 1 $(\mathrm{PM}>1)$.

Dari tabel 2 diperoleh nilai koefisien determinasi (Adjusted $R$ Square) sebesar 0,748 artinya kontribusi kontribusi kedua variabel bebas yang telah dibahas sebelumnya, yakni biaya usaha tani (X1) dan teknologi/traktor (X2) terhadap produksi pertanian/padi (Y) sebagai variabel terikat sebesar 74,80 persen. Disisi lain, hasil persamaan regressi sebagaimana ditampilkan pada tabel 2 juga harus memenuhi asumsi klasik, Uji multikolinearitas, Uji heteroskedastisitas, dan Uji autokorelasi. 
Tabel 2. Model Persamaan Regressi

\begin{tabular}{|c|c|c|c|}
\hline Variabel & $\begin{array}{c}\text { Unstandardized } \\
\text { Coefficients (Beta) }\end{array}$ & t hitung & Sign. \\
\hline Constant & $-1,045$ & & \\
\hline Biaya usaha tani $(\mathrm{X} 1)^{*}$ & 2,127 & 2,947 & 0,027 \\
\hline Teknologi/traktor $(\mathrm{X} 2)^{* * *}$ & 3,549 & 3,989 & 0,002 \\
\hline $\mathrm{R}$ & \multirow{5}{*}{$\begin{array}{l}=0,879 \\
=0,773 \\
=0,748 \\
=24,753 \\
=0,001\end{array}$} & & \\
\hline R Square & & & \\
\hline Adjusted $R$ Square & & & \\
\hline F hitung** & & & \\
\hline Sign. F & & & \\
\hline
\end{tabular}

Sumber: Data primer diolah

Keterangan: **signifikan pada taraf nyata 1 persen (sangat signifikan)

*signifikan pada taraf nyata 5 persen (signifikan)

Berdasarkan Uji multikolinearitas diperoleh nilai Variance Inflation Factor (VIF) untuk kedua variabel yaitu biaya usaha tani (X1) sebesar 5,235 dan teknologi/traktor (X2) sebesar 6,217.Nilai VIF untuk kedua variabel tersebut kurang dari 10 (VIF<10), sehingga dengan demikian tidak terjadi multikolinearitas. Berkaitan dengan heteroskedastisitas dengan menggunakan Uji Giejser untuk kedua variabel tersebut diperoleh $t$ hitung untuk biaya usaha tani (X1) sebesar 1,785 dengan signifikansi $0,097(0,097>0,05)$ dan $t$ hitung untuk teknologi/traktor (X2) sebesar 1,899 dengan signifikansi 0,087 $(0,087>0,05)$. Dimana nilai taraf signifikansi untuk kedua variabel tersebut baik untuk biaya usaha tani (X1) maupun teknologi/traktor (X2) lebih dari 0,05, dengan demikian tidak terjadi masalah heteroskedastisitas.

Berdasarkan Uji autokorelasi diperoleh nilai Durbin-Watson (DW) sebesar 1,735 dimana tidak terjadi autokorelasi, jika nilai Durbin-Watson (DW) terletak antara dU dan 4-dU (dU $<$ DW $<4-\mathrm{dU}$ ) dimana dU adalah nilai batas atas atau upper bound (Rawlings, 2011). Dalam penelitian ini jumlah sampel (n) adalah 58 $(\mathrm{n}=58)$ dan terdapat dua variabel bebas $(\mathrm{k}=2)$, sehingga dari tabel DW pada taraf signifikansi 0,05 diperoleh nilai dU sebesar 1,681 dan 4-dU sebesar 2,319. Dengan demikian, nilai DW sebesar 1,735 terletak antara dU dan 4-dU $(1,681<1,735<2,319)$, sehingga tidak terjadi autokorelasi.

\section{Strategi Pengembangan Teknologi}

Pada tahun 1950-anpara ekonom neoklasik yang dipelopori oleh Solow (1956) mengembangkan sebuah teori yang dikenal dengan teori pertumbuhan eksogen.Berkat teori pertumbuhan eksogen ini, Solow meraih Nobel Ekonomi pada tahun 1984.Dalam teori pertumbuhan eksogen, produksi nasional (output) yang menentukan pendapatan per kapita masyarakat maupun pertumbuhan ekonomi di suatu negara ditentukan oleh dua faktor produksi, yaitu kapital (modal) dan tenaga kerja.Hubungan produk nasional dengan kapital dan tenaga kerja bersifat eksponensial (bukan linear) berupa fungsi Cobb-Douglas.Kedua faktor produksi, kapital dan tenaga kerja bersifat constantreturn to scale, artinya apabila faktor produksi ditingkatkan secara proporsional, maka produk nasional juga akan meningkat dengan proporsi yang sama. Selain itu, peningkatan output (produksi)bersifat deminishing return to scale, artinya peningkatan output yang diperoleh karena tambahan 1 unit faktor produksi tidak sebesar peningkatan output dari tambahan 1 unit faktor produksi sebelumnya. Dalam pada itu, produk marginal (PM) kapital maupun tenaga kerja kurang dari 1 $(\mathrm{PM}<1)$.Dalam teori pertumbuhan eksogen, teknologi juga memberikan kontribusi terhadapproduksi nasional, tetapi kontribusinya bersifat eksogen. Disisi lain, teknologi merupakan barang publik (public goods), sehingga setiap negara memiliki peluang atau kesempatan sama untuk memanfaatkan teknologi dengan tanpa biaya samasekali.

Dalam teori pertumbuhan eksogen, negara maju (kaya) memiliki nisbah (rasio) kapital per tenaga kerja yang lebih besar, sehingga tingkat pengembalian kapitalnya rendah.Sebaliknya negara kurang maju (berkembang) memiliki nisbah modal per tenaga kerja lebih kecil, sehingga tingkat pengembalian kapitalnya tinggi.Oleh karena itu, terjadi aliran modal dari negara maju ke negara berkembang.Dengan demikian pertumbuhan pendapatan per kapita negara berkembang lebih cepat dibandingkan negara maju, dan pada gilirannya pertumbuhan pendapatan per kapita negara berkembang dapat menyamai negara maju dan ini dikenal dengan konvergensi.

Dengan menggunakan berbagai sumber data seperti data dari Maddison, Abramovitz dan HestonSummers kemudian Romer (1994) menyatakan bahwa konvergensi hanya terjadi selama perang Dunia ke-II selanjutnya antara tahun 1935 dan 1950 pendapatan per kapita cenderung divergen dan sepanjang periode 1960-1985 tidak terjadi konvergensi. Menurut Lucas (1990) bahwa aliran modal dari negara maju ke negara 
berkembang ternyata tidaklah mengalir secara merata, tetapi hanya mengalir pada negara tertentu yang memiliki prospek pertumbuhan tinggi.Ini menunjukkan bahwa konvergensi dalam teori pertumbuhan eksogen itu kurang didukung oleh data empiris.Untuk itu sejak tahun 1980-an, Romer (1994) memelopori pengembangan teori pertumbuhan endogen dimana teknologi bukanlah faktor eksogen, melainkan merupakan faktor endogen yang melekat dalam proses produksi itu sendiri. Teori pertumbuhan endogen ini yang menghantarkan Romer meraih Nobel Ekonomi pada tahun 2018.

Dalam teori pertumbuhan endogen, hubungan antara produk nasional dengan dua faktor produksi, yaknikapital dan teknologi bukan bersifat eksponensial, melainkan linear.Dalam penelitian ini, hubungan linear tersebut tercermin dalam persamaan regressi yang telah dibahas sebelumnya, yakni $\mathrm{Y}=$ $1.045+2,127 \mathrm{X} 1+3,549 \mathrm{X} 2$ dimana X1 adalah kapital (biaya usaha tani) dan X2 adalah teknologi/traktor dan $\mathrm{Y}$ adalah produksi pertanian (padi).Dari persamaan regressi tersebut diperoleh produk marginal (PM) untuk

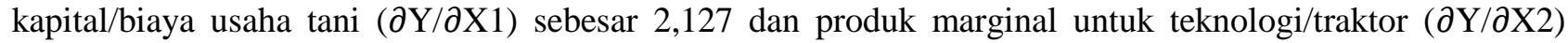
sebesar 3,549.Ini menunjukkan bahwa PM untuk kapital (biaya usaha tani) maupun teknologi (traktor) lebih dari 1 (PM>1).Teknologi dalam perspektif teori pertumbuhan endogen bukanlah barang publik, melainkan barang non-rivalry dan partially excludable (Romer, 1990). Artinya dalam konteks penelitian ini, yakni setiap petani dapat menggunakan teknologi (traktor) untuk kegiatan pengolahan tanah dalam usaha tani, tetapi tidak dengan tanpa biaya, melainkanharus mengeluarkan biaya untuk menyewa traktor maupun membeli traktor. Dari penelitian ini diperoleh bahwa sebagian besar petani (96,55 persen) menggunakan teknologi (traktor) dengan cara menyewa dan lainnya (3,45 persen) dengan cara membeli.

Penggunaan teknologi (traktor) tersebut menggambarkan bahwa perkembangan petani tidaklah statis sebagaimana dikemukakan Boeke (1953), melainkan dinamis dimana ketika petani dihadapkan dengan berkurangnya tenaga kerja manusia sebagai hambatan, mereka memiliki ide (gagasan) untuk menerapkan teknologi melalui proses learning by doing (Romer, 1990) dimana proses ini menyebabkan terjadinya perubahan dari unlearning yakni ditinggalkannya cara konvensional (tenaga kerja manusia) menjadi relearning yakni dengan diterapkannya teknologi (traktor).Berdasarkan hasil penelitian ini bahwa produktivitas pertanian (padi) yang diperoleh dari penggunaan teknologi (traktor) sebesar 6,83 ton per hektar atau lebih tinggi secara sangat signifikan dibandingkan produktivitas padi yang diperoleh secara konvensional (tenaga kerja manusia) sebesar 5,98 ton per hektar.Oleh karena itu, produktivitas pertanian (padi) dalam penelitian ini tidaklah statis, melainkan dinamis yakni mengalami peningkatan dari 5,98 ton per hektar menjadi 6,83 ton per hektar. Hasil penelitian ini berbeda dengan produktivitas pertanian statis (tanpa inovasi teknologi) yang dicetuskan Geertz (1976) dimana produktivitas pertanian yang statis inilah yang harus dibagi dengan penduduk yang jumlahnya terus bertambah yang pada giliranya melahirkan "berbagi kemiskinan". Disisi lain, Penny (1978) menggunakan istilah developmental minded untuk perkembangan petani yang bersifat dinamis tersebut dan menurut Penny (1978) petani tidak memiliki developmental minded. Hasil penelitian ini berbeda dengan Penny (1978) dimana petani justru memiliki developmental minded.

Dari hasil penelitian ini diperoleh bahwa perkembangan petani tidaklah statis, melainkan dinamis.Oleh karena itu, ide (gagasan) mengenai penelitian terapan di sektor pertanian digali dari petani itu sendiri kemudian ide (gagasan) itulah yang selanjutnya dijadikan topik penelitian terapan oleh berbagai lembaga penelitian.Hasil penelitian dari berbagai lembaga penelitian itu kemudian oleh pihak swasta dikembangkan menjadi teknologi yang dapat diterapkan oleh petani. Dalam konteks ini, maka peran pemerintah daerah (Dinas Pertanian) tidak lagi hanya sekedar sebagai penyedia barang publik, tetapi mendorong dan memfasilitasi terwujudnya kemitraan petani, lembaga penelitian, dan pihak swasta dalam penelitian dan pengembangan teknologi.Kemitraan ini hendaknya dikembangkan di setiap kecamatan dengan melibatkan Balai Penyuluh Pertanian (BPP) di masing-masing kecamatan.Dalam penelitian terapan sebaiknya digunakan pendekatan Participatory Action Research (PAR).

\section{SIMPULAN DAN SARAN}

\section{Simpulan}

1. Keragaan usaha tani meliputi tiga komponen, yaitu produktivitas, curahan kerja, dan biaya pengolahan tanah. Produktivitas pertanian (padi) yang diperoleh dari penggunaan teknologi (traktor) sebesar 6,83 ton/Ha atau lebih tinggi dibandingkan yang diperoleh secara konvensional (tenaga kerja manusia) sebesar 5,98 ton/Ha. Penggunaan teknologi (traktor) lebih efisien dibandingkan secara konvensional (tenaga kerja manusia) dimana curahan kerja dengan penggunaan teknologi (traktor) yakni 4,93 HOK lebih rendah dibandingkan secara konvensional sebesar 13,45 HOK. Biaya pengolahan tanah dengan penggunaan 
teknologi (traktor) sebesar Rp.1.104.000 per hektar lebih rendah dibandingkan secara konvensional (tenaga kerja manusia) sebesar Rp.2.125.000 per hektar.

2. Hubungan produksi pertanian (padi) sebagai variabel terikat dengan kedua faktor produksi, yaitu biaya usaha tani dan teknologi (traktor) sebagai variabel bebas bersifat linear. Kedua faktor produksi tersebut berpengaruh baik secara simultan maupun parsial terhadap produksi pertanian (padi). Produk marginal untuk biaya usaha tani maupun teknologi lebih dari 1 dimana produk marginal untuk biaya usaha tani dan teknologi (traktor) masing-masing sebesar 2,127 dan 3,549.

3. Perkembangan petani tidaklah statis, melainkan dinamis. Untuk itu, strategi pengembangan teknologi digali dari ide (gagasan) petani itu sendiri dan ide (gagasan) itulah yang selanjutnya dijadikan topik penelitian terapan oleh berbagai lembaga penelitian dan hasil penelitian tersebut selanjutnya oleh pihak swasta dikembangkan menjadi teknologi yang dapat diterapkan oleh petani.

\section{Saran-Saran}

1. Sebaiknya peran pemerintah daerah (Dinas Perrtanian) tidak lagi hanya sekedar sebagai penyedia barang publik, melainkan mendorong dan memfasilitasi terwujudnya kemitraan petani, lembaga penelitian, dan pihak swasta dalam penelitian dan pengembangan teknologi.

2. Kemitraan ini hendaknya dikembangkan di setiap kecamatan dengan melibatkan Balai Penyuluh Pertanian (BPP) di masing-masing kecamatan.

3. Dalam penelitian terapan yang dilakukan oleh berbagai lembaga penelitian sebaiknya digunakan pendekatan Participatory Action Research (PAR).

\section{DAFTAR PUSTAKA}

Anderson Sharon, 2010.Statistical Methods for Comparative Studies.JohnWiley \& Sons, New York.

Baker Scott B., 2017. Organization Development Primer:Change Management, Kurt Lewin and Beyond.IRC

Research Program, Queen University, Ontario, Canada.

Boeke, J.H., 1953. Economic and Economic Policy of Dual Societies.H.D.Tjeenk Willink \& Zoon, Haarlem.

Bratton John, 2011. Introduction to Work and Organizational behaviour.Third edition, Palgrave and McMillan Education, Basingstoke, United Kingdom.

Burn B, 2016. Kurt Lewin and Complexity Theories: Back to the future.Journal of Change Management, 4(4):309-325.

Cumming Stephen et al, 2016. Unfreezing Change as three steps: Rethinking Kurt Lewin legacy for Change Management, Human Relations, Vol.69 (1):33-60.

Djamhari S., 2009. Kajian Penerapan Mekanisasi Pertanian di Lahan Rawa LebakDesa Putuk Muara Enim. Jurnal Sains dan Teknologi Indonesia, Vol.11 No.2:157-161.

Geertz Clifford, 1976. Involusi Pertanian Proses Perubahan Ekologi di Indonesia. Bhatara Karya Aksara, Jakarta

Gunter Mc Grath R., 2014.Management's Three Eras: A Brief History. Harvard Business Review, July 30,2014 .

Haris Abdul, 2002. Memburu Ringgit Membagi Kemiskinan.Pustaka Pelajar, Yogyakarta.

Hughes Owen E., 2011. Public Management \& Administration: An Introduction.ST.Martin's Press Inc., New York.

Kathori CR \& Gaurav G., 2010.Research Methodology: Methods and Techniques. New Age International Publishing, New Delhi.

Lucas Robert E., 1990. Why Doesn't Capital Flow from Rich to Poor Countries. American Economic Review, Vol.80 No.2:92-96.

Penny D.H., 1978. Masalah Pembangunan Pertanian Indonesia.Penerbit PT.Gramedia, Jakarta.

Rawlings John et al, 2011. Applied Regression Analysis:Research Tool. Springer-Verlag, New York.

Romer, Paul M., 1994.The Origins of Endogenous Growth. Journal of Economic Perspective, Vol.8 (1):3-22.

Romer,Paul M., 1990.Endogenous Technological Change. Journal of Political Economy, Vol.98 (5):S71S102.

Solow Robert, 1956. A Contribution to the Theory of Economic Growth. Quartely Journal of Economics, February 1956, 70:65-04

Stacy RD., 2014. Strategic Management and Organizational Dynamics: The Challenge of Complexity.Fifth edition, Prantice Hall, New Jersey.

Swanson Donald J. et al, 2014. Sharpening the Focus of Force Field Analysis.Journal of Change Management, 14 (1):28-47. 